\title{
Greenhouse gas emissions and nitrogen efficiency of dairy cows of divergent economic breeding index under seasonal pasture-based management
}

\author{
B. Lahart, ${ }^{1,2}$ L. Shalloo, ${ }^{1}$ J. Herron, ${ }^{1}$ D. O'Brien, ${ }^{3}$ R. Fitzgerald, ${ }^{1}$ T. M. Boland, ${ }^{2}$ and F. Buckley ${ }^{1 *}$ \\ ${ }_{1}^{1}$ Teagasc, Animal and Grassland Research and Innovation Centre, Moorepark, Fermoy, Co. Cork, P61 C996, Ireland \\ ${ }^{2}$ School of Agriculture and Food Science, University College Dublin, Belfield, Dublin 4, D04 N2E5, Ireland \\ ${ }^{3}$ Crops, Environment, and Land Use Research Centre, Teagasc, Johnstown Castle, Co. Wexford, Y35 TC97, Ireland
}

\begin{abstract}
Greenhouse gas (GHG) emissions and nitrogen (N) efficiencies were modeled for 2 genetic groups (GG) of Holstein-Friesian cows across 3 contrasting feeding treatments (FT). The 2 GG were (1) high economic breeding index (EBI) animals representative of the top $5 \%$ of cows nationally (elite) and (2) EBI representative of the national average (NA). The FT represented (1) generous feeding of pasture, (2) a slight restriction in pasture allowance, and (3) a high-concentrate feeding system with adequate pasture allowance. Greenhouse gas and $\mathrm{N}$ balance models were parameterized using outputs generated from the Moorepark Dairy Systems model, a stochastic budgetary simulation model, having integrated biological data pertaining to the 6 scenarios $(2 \mathrm{GG} \times 3 \mathrm{FT})$ obtained from a 4-yr experiment conducted between 2013 and 2016. On a per hectare basis, total system GHG emissions were similar for both elite and NA across the 3 FT. Per unit of product, however, the elite group had $10 \%$ and $11 \%$ lower GHG emissions per kilogram of fat- and protein-corrected milk and per kilogram of milk solids (MSO; fat + protein $\mathrm{kg}$ ), respectively, compared with the NA across the $3 \mathrm{FT}$. The FT incorporating high concentrate supplementation had greater absolute GHG emissions per hectare as well as GHG per kilogram of fat- and protein-corrected milk and MSO. The elite group had a slightly superior $\mathrm{N}$ use efficiency ( $\mathrm{N}$ output/N input) and lower $\mathrm{N}$ surplus ( $\mathrm{N}$ input - $\mathrm{N}$ output) compared with the NA group. The high concentrate FT had an inferior N use efficiency and a higher $\mathrm{N}$ surplus. The results of the current study demonstrate that breeding for increased EBI will lead to a general improvement in GHG emissions per unit of product as well as improved $\mathrm{N}$ efficiency. The results also illustrate that reducing concentrate supplementation will reduce GHG emissions, GHG emissions in-
\end{abstract}

Received September 10, 2020.

Accepted February 23, 2021.

*Corresponding author: frank.buckley@teagasc.ie tensity, while improving $\mathrm{N}$ efficiency in the context of pasture-based dairy production.

Key words: grazing dairy cow, genetics, greenhouse gas emissions, nitrogen efficiency

\section{INTRODUCTION}

To meet the rising global demand for food while simultaneously minimizing negative environmental impacts, agricultural food production systems must engage in practices that maximize efficiencies and promote responsible use of resources. Due to its high nutritive value, milk is a key source of nutrition for the rapidly expanding global population (Mottet et al., 2018). In countries such as Ireland and New Zealand, milk production systems are predominantly based on a seasonal spring calving model where the primary feed source is grazed grass (Roche et al., 2018; O'Brien et al., 2018). Greenhouse gas (GHG) emissions associated with the production and transportation of imported feed are low in grazing systems (O'Brien et al., 2012). When GHG emissions are related to milk production, the carbon footprint of Irish dairy production systems compares favorably with other European Union (EU) countries (Leip et al., 2010; Kelly et al., 2020). The abolition of EU milk quotas has resulted in a rapid increase in both dairy cow numbers and production per cow in Ireland, contributing to a $47 \%$ growth in national milk solids (MSO; milk fat + protein $\mathrm{kg}$ ) production since 2014 (CSO, 2020). Greenhouse gas emissions from agriculture have increased by $8 \%$ in the same period (EPA, 2020). Thus, although Ireland is an efficient producer of agricultural commodities, its total agricultural GHG emissions are rising.

Water quality is another important issue facing agriculture. Ireland must preserve the quality of its water bodies to comply with the European Union Water Framework Directive (2000/60/EC). At present, 53\% Irish surface waters are in "good" ecological status. This figure has declined by $4.4 \%$ between the 2010-2015 and 2013-2018 water quality recording periods (EPA, 2019a). Grazing animals are not capable of utilizing 
excess dietary N (Keim and Anrique, 2011), which is excreted in urine or feces and can contribute to $\mathrm{N}$ loss in the form of nitrates into ground water and ammonia and nitrous oxide $\left(\mathrm{N}_{2} \mathrm{O}\right)$ in the air. Thus, systems that increase $\mathrm{N}$ efficiency within pasture-based dairy systems reduce the amounts of $\mathrm{N}$ available across the different loss pathways.

The contribution of genetics should be considered when assessing strategies to improve sustainability as breeding is cumulative and permanent, meaning any positive or deleterious effects of genetic selection will be compounded with successive generations. The economic breeding index (EBI) in Ireland has been developed to deliver genetics that increase profitability in pasture-based systems. Already published results demonstrate clear favorable responses in terms of MSO yield (O'Sullivan et al., 2019b), intake capacity and energy balance (O'Sullivan et al., 2019a), reproductive efficiency and longevity (O'Sullivan et al., 2020a), and economic performance (O'Sullivan et al., 2020b) via selection based on the EBI. To estimate the total environmental impact of selection using EBI, a multidisciplinary modeling approach integrating detailed production and fertility performance from experimental data and extrapolating to commercial farm scenarios is required. The objective of this study was to use GHG and $\mathrm{N}$ efficiency models parameterized from experimental data to investigate the effect of genetic selection using the EBI on GHG emissions and N efficiency across differing pasture-based milk production scenarios.

\section{MATERIALS AND METHODS}

\section{Study Details}

Data were available from the Next Generation Herd project at the Dairygold research farm over a 4-yr period (2013-2016). A detailed description of the study has been provided by O'Sullivan et al. (2019b). Briefly, 2 genetic groups (GG) of Holstein-Friesian cows were compared: a high EBI group, representing the top 5\% of Irish dairy cows ranked on EBI (elite), and a group representative of the national average genetic merit (NA). The mean (SD) EBI, milk, fertility, calving, beef, maintenance, management, and health subindices of the elite was €181 (51.7), €51 (27.2), €91 (48.1), €33 (12.1), -€13 (9.5), €14 (10.5), €3 (5.1), and €3 (6.5) and for the NA was $€ 82$ (54.9), €31 (24.1), €26 (46.2), $€ 22$ (13.8), -€9 (8.1), €11 (9.2), €1 (5.2), and €0 (7.1), respectively (Irish Cattle Breeding Federation, January 2020). In each of the $4 \mathrm{yr}, 90$ elite and 45 NA cows were randomly assigned to 1 of 3 experimental feeding treatments (FT): control (CTL), high concentrate (HC), and lower grass allowance (LGA). The CTL, HC, and
LGA FT were characterized by postgrazing residual sward heights of $4.7,4.7$, and $3.7 \mathrm{~cm}$, and concentrate supplementations per cow of $318,1,116$, and $313 \mathrm{~kg}$, respectively, across the $4 \mathrm{yr}$ of the study (O'Sullivan et al., 2019b). The $3 \mathrm{FT}$ were designed to determine genetic expression across pasture-based scenarios representative the upper and lower limits of recommended best practice to maximize productivity per cow and per hectare in Irish milk production systems (O'Donovan et al., 2011).

\section{Whole Farm Modeling}

Outputs were generated using the Moorepark Dairy Systems model (MDSM; Shalloo et al., 2004), a stochastic budgetary simulation model, having integrated biological data pertaining to the 6 scenarios (2 GG $\times 3 \mathrm{FT}$ ) obtained from the 4-yr experimental period. The analysis was based on a 40-ha farm carrying 110 cows. A detailed description of the modeling process has previously been described by O'Sullivan et al. (2020b). Feed intake of the herd was determined by the MDSM, meeting the cow's energetic requirements for milk production, pregnancy, BCS change, maintenance, and BW change (Jarrige, 1989). Milk production data from O'Sullivan et al. (2019b) and reproductive performance from O'Sullivan et al. (2020a) were used to parameterize the model representative of each of the 6 scenarios $(2 \mathrm{GG} \times 3 \mathrm{FT})$ of interest. Replacement rate was determined by the proportion of cows that failed to become pregnant (involuntary culling) by the end of the breeding season $(6.3 \%$ and $16.9 \%$ for the elite and NA, respectively; O'Sullivan et al., 2020a) plus $2 \%$ for mortality and $8 \%$ for voluntary culling of the remaining animals (Hutchinson et al., 2013). Fertility differed between the 2 GG but was not significantly different across the $3 \mathrm{FT}$ over the $4 \mathrm{yr}$ of the study (O'Sullivan et al., 2020a); therefore, replacement rate was assumed similar across FT for each GG. All calves were assumed sold at $4 \mathrm{wk}$ of age and replacements were assumed to be bought (reflective of costings for contract rearing of heifers) in 1 mo before calving. Milk output reflected the impact of differences in parity structure accruing due to differences in fertility, while milk fat, protein, and lactose concentrations were as observed by O'Sullivan et al. (2019b). Pasture growth rates, quality, and utilization were inputted into the model to calculate feed demand based on the descriptions above. The outputs of the model are presented in Table 1.

Greenhouse Gas Emissions. The Moorepark GHG model (O'Brien et al., 2010) was used to estimate GHG emissions for the 6 scenarios $(2 \mathrm{GG} \times 3 \mathrm{FT})$ in conjunction with the outputs of the MDSM through a life cycle assessment approach. This model calculates 
GHG emissions from on- and off-farm activities using a range of published emission factors, creating a static account of all GHG emissions produced from the system up until the point of milk leaving the farm. The on-farm sources represent emissions from day-to-day farming activities and comprise methane $\left(\mathrm{CH}_{4}\right)$ from enteric fermentation and excreted manure, direct $\mathrm{N}_{2} \mathrm{O}$ emissions, and carbon dioxide $\left(\mathrm{CO}_{2}\right)$ from fuel combustion. Methane from enteric fermentation, manure excreted at pasture, and manure stored during housing were calculated using the IPCC (2019) tier 2 methodology. Direct $\mathrm{N}_{2} \mathrm{O}$ emissions originate from 3 sources: application of synthetic fertilizer, manure deposition, and manure management. The type of synthetic fertilizer influences $\mathrm{N}_{2} \mathrm{O}$ emissions; thus, specific $\mathrm{N}_{2} \mathrm{O}$ emission factors developed by Harty et al. (2016) were used. Direct $\mathrm{N}_{2} \mathrm{O}$ emissions from fecal and urine deposition during grazing also vary significantly with climatic and environmental conditions; thus, specific $\mathrm{N}_{2} \mathrm{O}$ emission factors derived under Irish grazing conditions by Krol et al. (2016) were used. Direct $\mathrm{N}_{2} \mathrm{O}$ emissions from manure management were calculated using the IPCC (2019) tier 2 methodology. Ammonia volatilized from manure management systems and during grazing were calculated using a N mass flow approach (EPA, 2019b). As stated in the national inventory report (EPA, 2019c), $10 \%$ of $\mathrm{N}$ applied was assumed lost through nitrate leaching. Carbon dioxide emissions from fuel combustion were calculated using emissions factors derived by the EPA (2019c). The off-farm emission sources originate from manufacture and transportation of fertilizer, lime, concentrate, forage, and milk replacer, as well as electricity generation and other off-farm inputs. A full range of the emission factors used can be found in Tables 2 and 3.

Greenhouse gas emissions estimated within the model were $\mathrm{CH}_{4}, \mathrm{~N}_{2} \mathrm{O}$, and $\mathrm{CO}_{2}$, which were expressed relative to their 100-yr global warming potential $\left[\mathrm{CO}_{2}\right.$ equiva- lents $\left(\mathbf{C O}_{2}\right.$-eq)]. This methodology sets the $\mathrm{CO}_{2}$-eq on a weight basis at 28 per $\mathrm{kg}$ of $\mathrm{CH}_{4}$ and 265 per $\mathrm{kg}$ of $\mathrm{N}_{2} \mathrm{O}$ (Myhre et al., 2013). An economic allocation was used to distribute emissions between milk and meat based on farm receipts reported by O'Sullivan et al. (2020b). Two metrics were used to calculate the GHG emissions of the GG across the 3 FT: (1) to quantify emissions on an area basis, emissions were expressed per hectare ( $\mathrm{t}$ of $\mathrm{CO}_{2}$-eq/ha); (2) to quantify emissions intensity per unit of production, emissions were expressed relative to fat- and protein-corrected milk (FPCM; $\mathrm{kg}$ of $\mathrm{CO}_{2}$-eq/ $\mathrm{kg}$ of FPCM) and MSO yield ( $\mathrm{kg}$ of $\mathrm{CO}_{2}$-eq/ $\mathrm{kg}$ of MSO).

The influence of carbon sequestration on GHG emissions was included as a further dimension. Three studies that measured carbon sequestration in Ireland were used (Byrne et al., 2005, 2007; Jaksic et al., 2006) to derive an average carbon sequestration rate of 742 kg per ha, which was subsequently applied within the model.

Nitrogen Balance. To investigate the influence of the GG and FT on N efficiency at the farm system level, the outputs of the MDSM were used to construct a $\mathrm{N}$ balance model similar to that described by Ryan et al. (2011). The model accounted for $\mathrm{N}$ inputs and outputs within the system to quantify $\mathrm{N}$ balances on a per hectare ( $\mathrm{kg}$ of $\mathrm{N} / \mathrm{ha}$ ) basis. Nitrogen inputs to the system were in the form of concentrate, silage, fertilizer, and livestock (herd replacements). Nitrogen entering the system in the form of fertilizer was expressed as kilograms of $\mathrm{N}$ applied/hectare. The $\mathrm{N}$ imported in concentrate and silage was calculated by dividing the CP content of the feed by 6.25 (McDonald, 2002). Nitrogen entering the system in replacement animals was calculated as follows: $\mathrm{BW}$ (mature $\mathrm{BW} \times 0.80) \times \mathrm{N}$ content of the animal $(0.024 \mathrm{~kg}$ of $\mathrm{N} / \mathrm{kg}$ of BW; ARC, $1994) \times$ herd replacement rate. Nitrogen outputs from the system were quantified as those from milk, and meat

Table 1. Effect of genetic group of Holstein-Friesians ${ }^{1}$ and feeding treatment $(\mathrm{FT})^{2}$ on physical model outputs on a 40-ha farm

\begin{tabular}{|c|c|c|c|c|c|c|}
\hline \multirow[b]{2}{*}{ Item } & \multicolumn{2}{|c|}{ LGA } & \multicolumn{2}{|c|}{ CTL } & \multicolumn{2}{|c|}{$\mathrm{HC}$} \\
\hline & Elite & NA & Elite & NA & Elite & NA \\
\hline Annual milk produced $(\mathrm{kg})$ & 576,033 & 576,957 & 623,476 & 580,917 & 687,175 & 649,277 \\
\hline Annual milk solids produced $(\mathrm{kg})$ & 48,814 & 45,397 & 53,074 & 46,179 & 57,752 & 51,480 \\
\hline Annual $\mathrm{FPCM}^{3}$ produced $(\mathrm{kg})$ & 620,793 & 584,243 & 672,672 & 594,057 & 732,072 & 660,854 \\
\hline \multicolumn{7}{|l|}{ Feed budget (kg of DM/cow) } \\
\hline Concentrate & 318 & 316 & 315 & 314 & 1,116 & 1,102 \\
\hline Total feed & 5,255 & 5,197 & 5,243 & 4,996 & 5,900 & 5,706 \\
\hline
\end{tabular}

${ }^{1}$ Elite $=$ high economic breeding index $(\mathrm{EBI}) ; \mathrm{NA}=$ national average EBI.

${ }^{2} \mathrm{CTL}=$ high grass allowance $\mathrm{FT} ; \mathrm{HC}=$ high-concentrate FT; LGA = lower grass allowance FT.

${ }^{3}$ Fat- and protein-corrected milk; predicted using the formula of the International Dairy Federation (IDF, 2010). 
Table 2. Emission factors used for greenhouse gas (GHG) emission sources from pasture-based dairy production systems

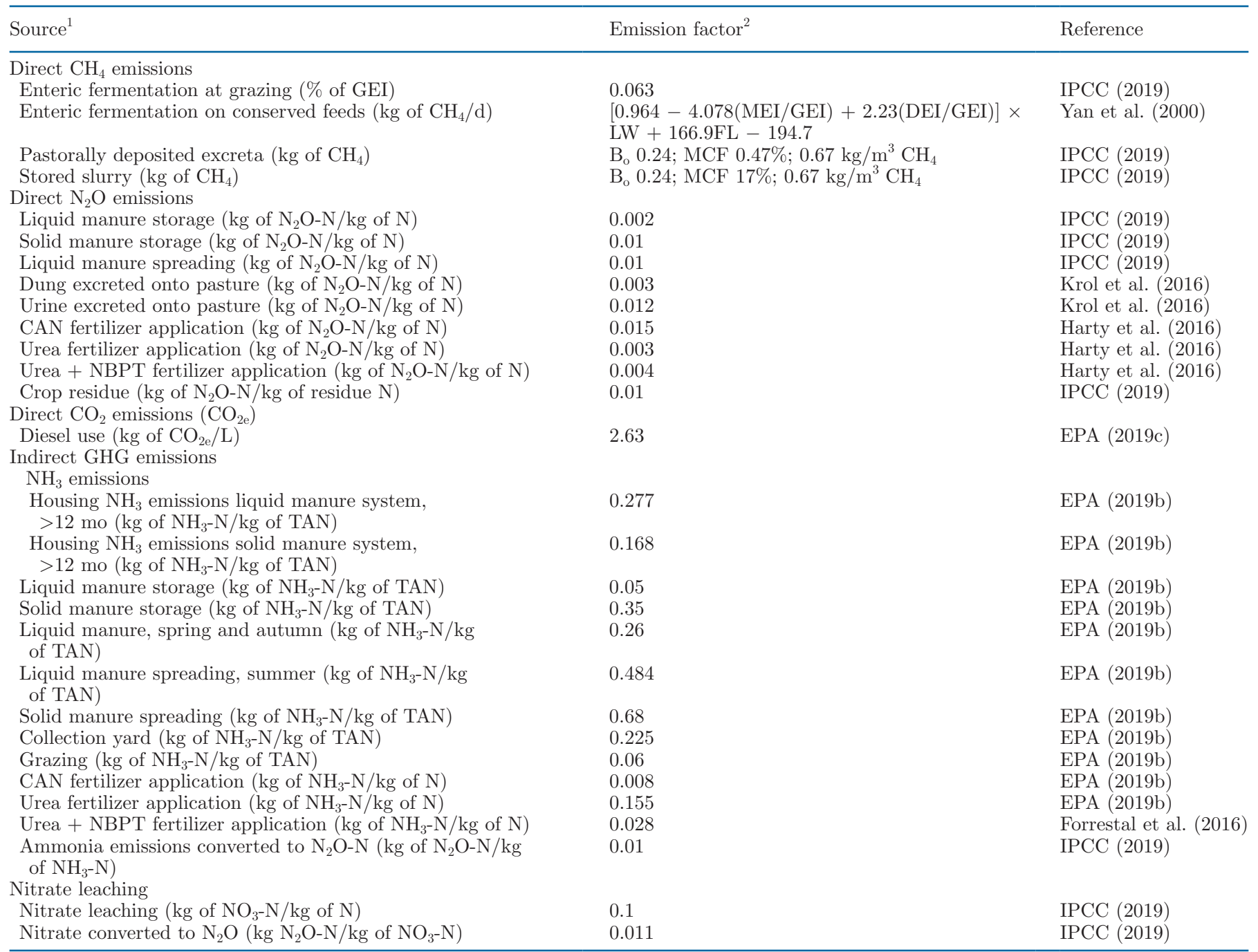

$\overline{{ }^{1} \mathrm{GEI}}=$ gross energy intake $(\mathrm{MJ}) ; \mathrm{CAN}=$ calcium ammonium nitrate; NBPT $=N$-(n-butyl)-thiophosphoric triamide; TAN $=$ total ammoniacal nitrogen.

${ }^{2} \mathrm{MEI}=$ metabolizable energy intake $(\mathrm{MJ}) ; \mathrm{DEI}=$ digestible energy intake $(\mathrm{MJ}) ; \mathrm{LW}=$ live weight $(\mathrm{kg}) ; \mathrm{FL}=$ feeding level; $\mathrm{B}_{\mathrm{o}}=$ methaneproducing capacity; MCF = methane conversion factor.

Table 3. Greenhouse gas emissions and other pollutants emitted during the manufacturing and transport of key imported farm inputs (emissions from inputs were sourced from Ecoinvent, 2010, unless otherwise indicated)

\begin{tabular}{lcccccccccc}
\hline Item & $\begin{array}{c}\mathrm{CO}_{2} \\
(\mathrm{~kg})\end{array}$ & $\begin{array}{c}\mathrm{CH}_{4} \\
(\mathrm{~g})\end{array}$ & $\begin{array}{c}\mathrm{N}_{2} \mathrm{O} \\
(\mathrm{g})\end{array}$ & $\begin{array}{c}\mathrm{NH}_{3} \\
(\mathrm{~g})\end{array}$ & $\begin{array}{c}\mathrm{NOx} \\
(\mathrm{g})\end{array}$ & $\begin{array}{c}\mathrm{NO}_{3} \\
(\mathrm{~g})\end{array}$ & $\begin{array}{c}\mathrm{SO}_{2} \\
(\mathrm{~g})\end{array}$ & $\begin{array}{c}\mathrm{PO}_{4} \\
(\mathrm{~g})\end{array}$ & $\begin{array}{c}\mathrm{P} \\
(\mathrm{g})\end{array}$ & $\begin{array}{c}\mathrm{Nonrenewable} \\
\text { energy }(\mathrm{MJ})\end{array}$ \\
\hline Electricity $^{1}(\mathrm{kWh})$ & 0.46 & 0.01 & 0.02 & 0.00 & 0.53 & 0.00 & 0.73 & 0.00 & 0.00 & $7.70^{2}$ \\
Diesel (L) & 0.38 & 1.51 & 0.01 & 0.00 & 1.58 & 0.01 & 4.16 & 0.00 & 0.00 & 8.23 \\
$\mathrm{CAN}^{3}(\mathrm{~kg}$ of N) & 3.35 & 2.63 & 1.06 & 8.84 & 13.98 & 0.00 & 4.08 & 0.00 & 0.00 & $43.63^{4}$ \\
Urea $^{3}$ (kg of N) & 1.83 & 0.00 & 0.39 & 3.49 & 3.21 & 0.01 & 3.13 & 0.00 & 0.00 & $50.98^{4}$ \\
Cow concentrate $(\mathrm{kg})$ & 0.27 & 2.60 & 0.35 & 1.43 & 0.62 & 9.91 & 0.49 & 0.22 & 0.00 \\
\hline
\end{tabular}

${ }^{1}$ Kilowatt-hour; $\mathrm{CO}_{2}, \mathrm{CH}_{4}$, and $\mathrm{N}_{2} \mathrm{O}$ emissions sourced from Ireland's national inventory report 2019 (EPA, 2019c).

${ }^{2}$ Megajoules of electricity production from SEAI (2018).

${ }^{3}$ Carbon dioxide, $\mathrm{CH}_{4}$, and $\mathrm{N}_{2} \mathrm{O}$ emissions from Brentrup et al. (2016); calcium ammonium nitrate (CAN): $27.5 \% \mathrm{~N}, \mathrm{urea} 46 \% \mathrm{~N}$.

${ }^{4}$ Megajoules of fertilizer production from Brentrup and Palliére (2011). 
in calves and cull cows. Nitrogen exported in milk was calculated as $[($ protein $\% \div 6.38) \times$ milk yield; ARC, 1994]. Nitrogen leaving the system in calves and cull cows were calculated as $\mathrm{BW} \times \mathrm{N}$ content of the animal $(0.029 \mathrm{~kg}$ of $\mathrm{N} / \mathrm{kg}$ of $\mathrm{BW}$ for calves and $0.024 \mathrm{~kg}$ of N/ $\mathrm{kg}$ of BW for cull cows; ARC, 1994). The total system $\mathrm{N}$ surplus was calculated by subtracting the total $\mathrm{N}$ output from the total $\mathrm{N}$ input. Nitrogen use efficiency was calculated as total $\mathrm{N}$ output $\div$ total $\mathrm{N}$ input.

\section{RESULTS}

\section{Greenhouse Gas Emissions}

The contribution of the different sources of GHG emissions for the 6 production scenarios is presented in Table 4. The relative contribution of both on and offfarm GHG emissions were similar for both the elite and NA across all FT. Although the source of the on-farm emissions differed between the $2 \mathrm{GG}$, the increased parity structure of the elite resulted in greater GHG emissions from enteric $\mathrm{CH}_{4}$ production, whereas the NA had greater GHG emissions associated with rearing extra replacements as a consequence of their poorer fertility and survival. From a FT perspective, HC had greater GHG emissions compared with the CTL and LGA associated with the growing, manufacture, and transportation of the additional concentrate feed. A breakdown of the emissions profile (both on and off farm) showed similar proportions of $\mathrm{CO}_{2}, \mathrm{CH}_{4}$, and $\mathrm{N}_{2} \mathrm{O}$ for both elite and NA. The HC had slightly greater proportions of
$\mathrm{CO}_{2}$ and slightly lower proportions of $\mathrm{CH}_{4}$ and $\mathrm{N}_{2} \mathrm{O}$ compared with the CTL and LGA.

The influence of GG and FT on GHG emissions expressed as $\mathrm{CO}_{2}$-eq are presented in Table 5 . The emissions are presented as both on-farm and total emissions expressed per unit of land and per unit of production. Total system GHG emissions per hectare were similar for both GG across all FT. When emissions were expressed per unit of FPCM, the elite group had lower total GHG emissions compared with the NA. Similarly, when expressed per unit of MSO, the elite group had lower GHG emissions compared with the NA. The HC had greater total GHG emissions per ha than the CTL and LGA. The CTL had lower total GHG emissions when expressed relative to FPCM compared with the LGA and HC with a similar trend evident when expressed relative to MSO production. The most efficient system (elite cows within the CTL) produced $17 \%$ and $19 \%$ less GHG emissions when expressed relative to FPCM and MSO, respectively, compared with the least efficient system (NA cows within the HC).

The influence of carbon sequestration on $\mathrm{t}$ of $\mathrm{CO}_{2}$ $\mathrm{eq} / \mathrm{ha}$ and $\mathrm{kg}$ of $\mathrm{CO}_{2}$-eq/ $\mathrm{kg}$ of $\mathrm{FPCM}$ is presented in Figure 1. On average, the inclusion of carbon sequestration resulted in a $16.8 \%$ reduction in $\mathrm{t}$ of $\mathrm{CO}_{2}$-eq/ha across all scenarios. The effect on elite and NA groups was similar. The influence of carbon sequestration on the CTL and LGA was similar $(-17.7 \%$ and $-17.8 \%$, $\mathrm{CO}_{2}$-eq, $\mathrm{t} / \mathrm{ha}$, respectively), whereas the $\mathrm{HC}$ observed a smaller decrease $\left(-15 \%\right.$ t of $\mathrm{CO}_{2}$-eq/ha). An identical trend held for kilograms of $\mathrm{CO}_{2}$-eq/kg of FPCM.

Table 4. Contribution (\%) of greenhouse gas emissions toward each genetic group of Holstein-Friesians ${ }^{1}$ and feeding treatment $(\mathrm{FT})^{2}$

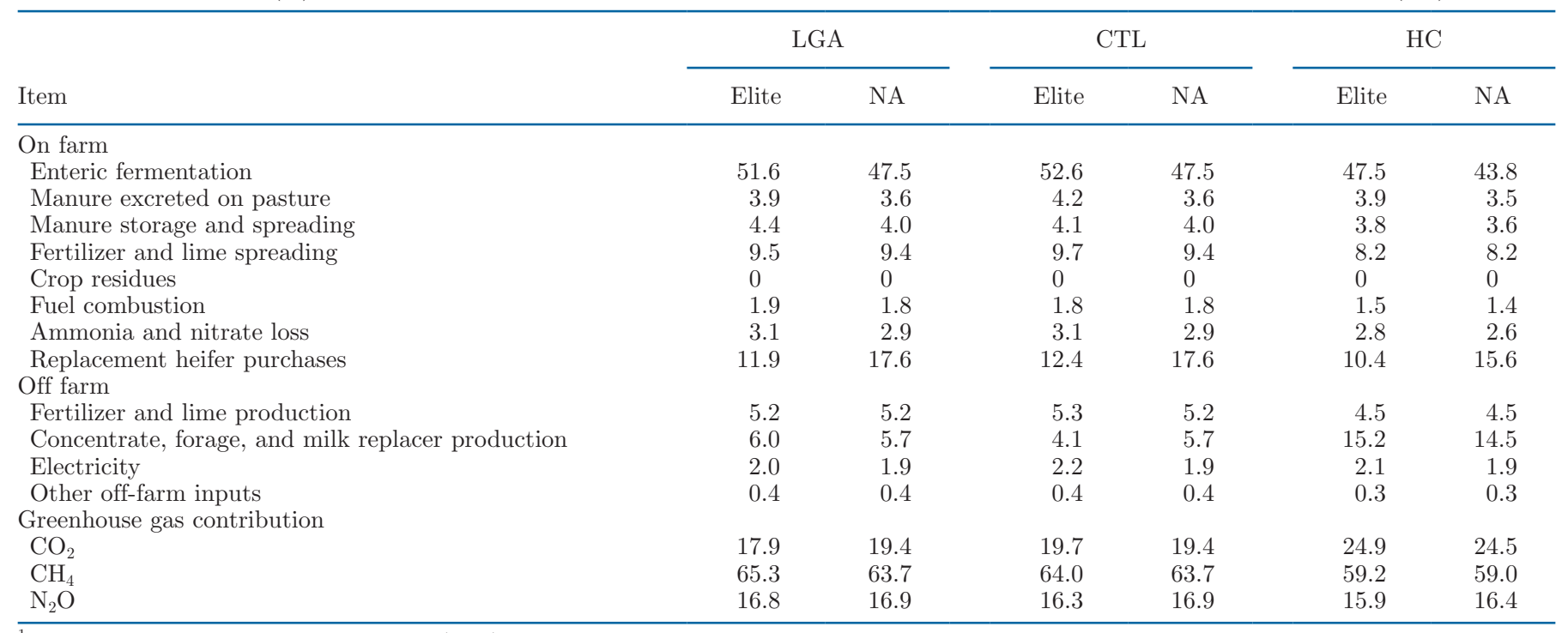

${ }^{1}$ Elite $=$ high economic breeding index $(\mathrm{EBI}) ; \mathrm{NA}=$ national average EBI.

${ }^{2} \mathrm{CTL}=$ high grass allowance $\mathrm{FT} ; \mathrm{HC}=$ high concentrate FT; LGA = lower grass allowance FT. 


\section{Nitrogen Efficiency}

The influence of GG and FT on farm gate N balance is presented in Table 6 . Total $\mathrm{N}$ input was similar for the elite and the NA across all FT. The elite group, however, had a greater $\mathrm{N}$ output compared with the NA, which contributed to their lower $\mathrm{N}$ surplus compared with the NA. Nitrogen use efficiency was greater for the elite group, compared with the NA. The HC had a greater $\mathrm{N}$ input compared with the CTL and the LGA. Additionally, the $\mathrm{HC}$ had a greater $\mathrm{N}$ output compared with the CTL and LGA. The HC had the greatest N surplus compared with the CTL and LGA. In terms of N use efficiency, the CTL and LGA were similar, whereas the HC was slightly less efficient. The elite cows within the CTL and elite cows within the LGA were the most superior systems for $\mathrm{N}$ use efficiency and $\mathrm{N}$ surplus, respectively, whereas the NA cows within the $\mathrm{HC}$ was the poorest system for the 2 metrics.

\section{DISCUSSION}

Breeding objectives should be consistently monitored to validate genetic gain and to ensure the compatibility of the genetics with the production system (O'Sullivan et al., 2019b). In response to evidence from controlled (Buckley et al., 2000; Snijders et al., 2001) and commercial studies (Evans et al., 2002; Buckley et al., 2003), the EBI was introduced in the early 21st century to identify optimal genetics to enhance profitability within Irish grazing systems (Veerkamp et al., 2002). Research using commercial (Ramsbottom et al., 2012) and experimental data (O'Sullivan et al., 2020b) has validated that selection for the EBI increases farm profit. Recent environmental pressures facing the dairy industry, however, also necessitates milk to be produced in an environmentally sustainable manner. Using commercial farm data, O'Brien et al. (2016) reported that herd EBI was associated with reduced GHG emissions per kilogram of FPCM. Such analysis, however, cannot definitively isolate the influence of genetic selection from management. The current study has estimated the environmental impact of animals of divergent EBI using data from a controlled research study (O'Sullivan et al., 2019a,b, 2020a,b). Although the study is relatively small in scale, the controlled nature of the study allows for the quantification of genetic selection independent of biases relating to management. However, a further approach could be to model the environmental impact of the EBI based on observed national genetic trends.

Despite increased productivity (O'Sullivan et al., 2019b, 2020b), elite animals do not have increased GHG emissions on a per unit of land basis, albeit there were differences in the source of emissions across both GG. The increased parity structure of the elite resulted in greater feed intake with a consequent increase in GHG emissions associated with enteric $\mathrm{CH}_{4}$ from the lactating herd. These emissions were offset, however, by lower GHG emissions associated with rearing less replacements compared with the NA group. Greater productivity improves emissions intensity through a dilution effect (Capper et al., 2009; Gerber et al., 2011). Greater productivity in the elite group led to $10 \%$ and $11 \%$ lower emissions ( $\mathrm{kg}$ of $\mathrm{CO}_{2}-\mathrm{eq} / \mathrm{kg}$ of $\mathrm{FPCM}$ and $\mathrm{kg}$ of $\mathrm{CO}_{2}$-eq $/ \mathrm{kg}$ of MSO, respectively) compared with the NA group. O'Sullivan et al. (2020b) demonstrated that $78 \%$ of the increased productivity with the elite group was due to their superior reproductive performance and consequent increased herd age structure and productivity potential. Thus, the majority of the increased dilution observed with the elite group was due to more animals reaching their productive potential as a result of greater fertility and survival in conjunction with a modest increase in absolute yield potential.

Some farmers will replace the same number of cows annually irrespective of how many nonpregnant cows there are at the end of the breeding season, possibly neutralizing the positive impact of selection for the EBI

Table 5. Effect of genetic group of Holstein-Friesians ${ }^{1}$ and feeding treatment $(\mathrm{FT})^{2}$ on greenhouse gas emissions

\begin{tabular}{|c|c|c|c|c|c|c|c|}
\hline Item $^{3}$ & Source & \multicolumn{2}{|c|}{ LGA } & \multicolumn{2}{|c|}{ CTL } & \multicolumn{2}{|c|}{$\mathrm{HC}$} \\
\hline $\mathrm{t}$ of $\mathrm{CO}_{2}-\mathrm{eq} / \mathrm{ha}$ & Total & 15.2 & 15.4 & 15.2 & 15.5 & 18.2 & 18.0 \\
\hline \multirow[t]{2}{*}{$\mathrm{kg}$ of $\mathrm{CO}_{2}-\mathrm{eq} / \mathrm{kg}$ of $\mathrm{FPCM}$} & On farm & 0.85 & 0.92 & 0.79 & 0.90 & 0.78 & 0.86 \\
\hline & Total & 0.98 & 1.06 & 0.90 & 1.04 & 1.00 & 1.09 \\
\hline $\mathrm{kg}$ of $\mathrm{CO}_{2}-\mathrm{eq} / \mathrm{kg}$ of $\mathrm{MSO}$ & On farm & 10.8 & 11.8 & 10.1 & 11.6 & 9.9 & 11.0 \\
\hline
\end{tabular}

${ }^{1}$ Elite $=$ high economic breeding index $(\mathrm{EBI}) ; \mathrm{NA}=$ national average EBI.

${ }^{2} \mathrm{CTL}=$ high grass allowance; $\mathrm{HC}=$ high concentrate; LGA $=$ lower grass allowance FT.

${ }^{3}$ Tonnes of $\mathrm{CO}_{2}$-eq/ha $=$ greenhouse gas emissions expressed per hectare; $\mathrm{kg}$ of $\mathrm{CO}_{2}$-eq $/ \mathrm{kg}$ of $\mathrm{FPCM}=$ greenhouse gas emissions expressed per kilogram of fat- and protein-corrected milk; $\mathrm{kg}$ of $\mathrm{CO}_{2}$-eq $/ \mathrm{kg}$ of MSO = greenhouse gas emissions expressed relative to milk solids production. 
on emissions associated with rearing less replacements. Over the longer term, however, the superior fertility in high EBI herds will give the farmer more confidence to carry less replacement animals. High EBI herds will also likely have less voluntary culling for SCC and lameness issues, as the EBI is selecting for reduced incidence of these traits (O'Connor et al., 2020). Thus, there will be more scope to cull later calving and poor yielding cows from the herd, which will increase productivity and dilute emissions even further.

On average, each incremental increase in EBI unit between the NA and elite resulted in a reduction of $0.0011 \mathrm{~kg}$ of $\mathrm{CO}_{2}-\mathrm{eq} / \mathrm{kg}$ of FPCM. At the current rate of genetic gain for EBI ( $€ 10$ per annum; www.icbf .com), this equates to a $1 \%$ reduction in emissions intensity per year, which is in agreement with Amer et al. (2018). At present, the national average $\mathrm{kg}$ of $\mathrm{CO}_{2}$-eq/ $\mathrm{kg}$ of FPCM is 1.13 in Ireland (Teagasc, 2020). Over a 10-yr period, selection using EBI in its current form would lead to a reduction in the average $\mathrm{kg}$ of $\mathrm{CO}_{2}$-eq/ $\mathrm{kg}$ of FPCM to 1.02 nationally through genetic gain alone. Similarly, Zhang et al. (2019) reported that genetic selection for the New Zealand breeding worth will lead to reduced $\mathrm{CH}_{4}$ emissions per kilogram of milk protein equivalents due to increased productivity and could potentially reduce national $\mathrm{CH}_{4}$ emissions as fewer cows will be required. Nonetheless, limiting milk output potential from countries such as Ireland and New Zealand may have a negative effect on global emissions, as it may allow countries with higher emission
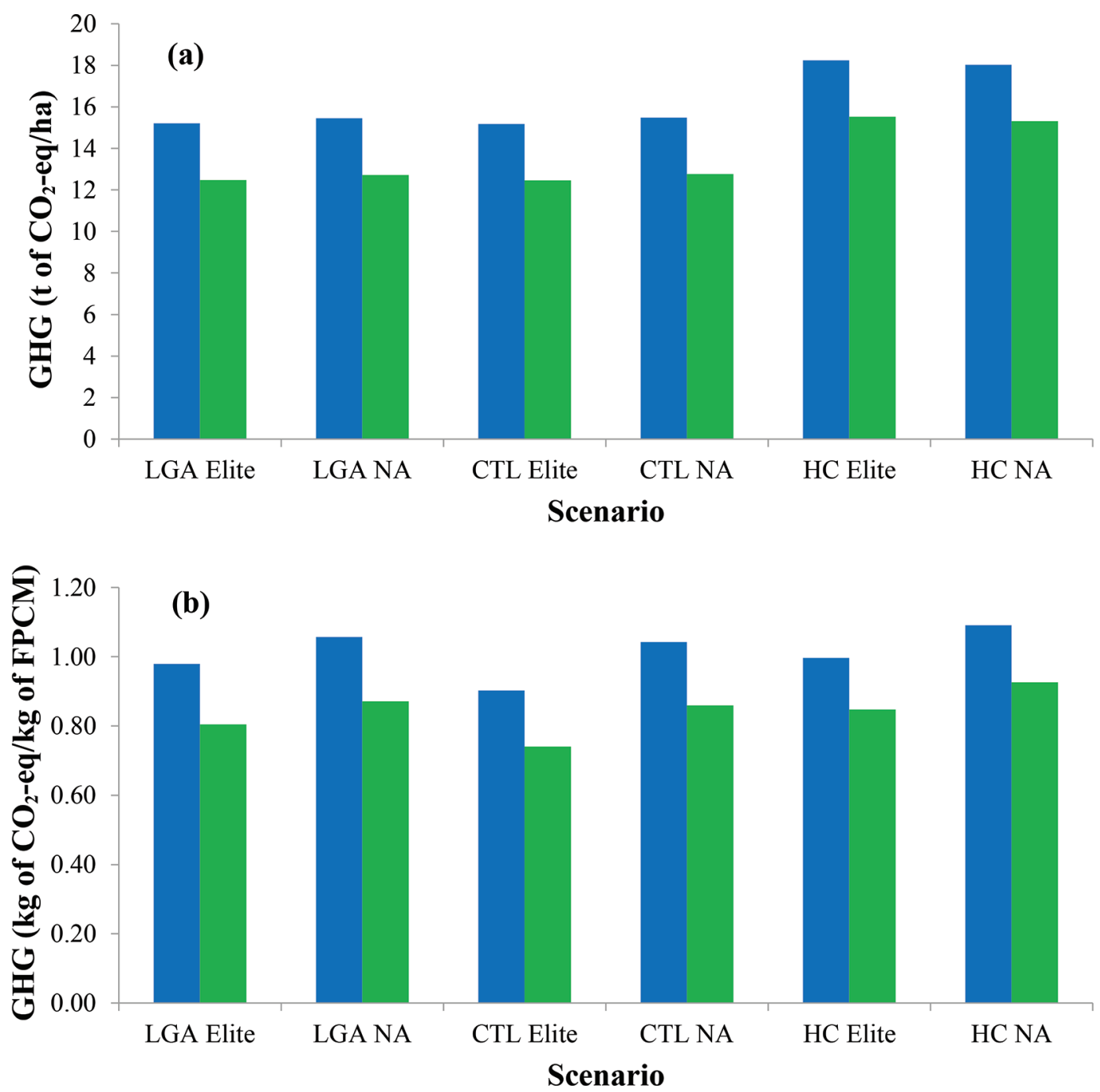

Figure 1. Greenhouse gas (GHG) emissions expressed per hectare ( $\mathrm{t}$ of $\mathrm{CO}_{2}$ equivalents/ha; a) and GHG emissions expressed per kilogram of fat- and protein-corrected milk ( $\mathrm{kg}$ of $\mathrm{CO}_{2}$ equivalents $/ \mathrm{kg}$ of FPCM; b) across the 6 scenarios $[(2$ genetic groups: Elite $=$ high economic breeding index; NA = national average economic breeding index $) \times(3$ feeding treatments: LGA $=$ lower grass allowance; CTL $=$ control; and $\mathrm{HC}=$ high concentrate)] without carbon sequestration (blue bars) and with carbon sequestration (green bars). 
intensities to increase milk production to meet global demand (Zhang et al., 2019; Kelly et al., 2020).

Zhang et al. (2019) reported that genetic gain within the New Zealand breeding worth could lead to increased concentrate supplementation to meet genetic potential for milk production. Similar to Zhang et al. (2019), the current results demonstrate the $\mathrm{HC}$ will increase GHG emissions per hectare compared with the CTL and LGA. The increased GHG emissions in the $\mathrm{HC}$ are predominantly associated with increased emissions from the production and transportation of the concentrate supplement as well as increased enteric fermentation due to greater feed intakes. In agreement with O'Brien et al. (2015), the increased milk output in the $\mathrm{HC}$ was not sufficient to dilute the increased emissions associated with the concentrate. Refining pasture-based management systems to increase grass utilization and reduce concentrate supplementation can reduce both GHG emissions and GHG emissions intensity. Reducing concentrate supplementation also has potential implications on global-food feed competition, as less human edible food (such as barley and soybean meal in the concentrate) is fed to the herd, increasing the global supply of food (Schader et al., 2015).

A feature of pasture-based systems is their ability to sequester carbon. The majority of studies evaluating GHG emissions within pasture-based systems, however, do not consider this metric (O'Brien et al., 2012). Similarly the current IPCC methodology for accounting GHG emissions within Irish national inventories does not take carbon sequestration from the atmosphere into consideration. This is due to a lack of detailed information in this area. Using available literature on carbon sequestration from Irish pasture-based systems, the current study estimated GHG emissions per hectare may be $16.8 \%$ lower across the 6 pasture-based systems when including a carbon sequestration rate of $742 \mathrm{~kg} /$ ha. Similarly on a national scale, GHG emissions within pasture-based systems are likely to be substantially lower than accounted for at present if sequestration was included. Further research is required, however, to accurately quantify carbon sequestration levels within Ireland.

The high protein levels in fresh grass pose problems within grazing systems, as dairy cows are not capable of utilizing excess dietary protein. This is a primary reason for low $\mathrm{N}$ efficiencies when compared with confinement systems (Powell et al., 2010). Genetic selection for the EBI appears to have a favorable, albeit slight, effect on $\mathrm{N}$ efficiency via greater productivity combined with lower $\mathrm{N}$ entering the system in herd replacements. The findings of the current study do however, demonstrate that management has a greater influence on $\mathrm{N}$ efficiency. The HC had a 31.9 and $43.1 \mathrm{~kg}$ greater $\mathrm{N}$ surplus per ha compared with the CTL and LGA, respectively. Indicating the additional $\mathrm{N}$ leaving the farm in milk was not sufficient to dilute the increased $\mathrm{N}$ surplus in the $\mathrm{HC}$ due to the additional $\mathrm{N}$ in concentrates entering the farm gate. This is despite high responses in terms of additional milk per kilogram of concentrate offered (O'Sullivan et al., 2019b). Reducing the protein content of concentrate may be a strategy to improve $\mathrm{N}$ utilization efficiency at the individual cow level (Keim and Anrique, 2011), although a high milk response is still required from high-concentrate systems to dilute the additional $\mathrm{N}$ in concentrate entering the farm gate. In the context of the current study, the LGA had the lowest $\mathrm{N}$ surplus, indicating increasing grazing pressure while holding animal numbers on the grazing platform constant confers advantages to $\mathrm{N}$ efficiency. This is a consequence of more silage being conserved on the grazing platform, resulting in a lower require-

Table 6. Effect of genetic group of Holstein-Friesians ${ }^{1}$ and feeding treatment $(\mathrm{FT})^{2}$ on farm gate N balance (kg of N/ha)

\begin{tabular}{|c|c|c|c|c|c|c|}
\hline \multirow[b]{2}{*}{ Item } & \multicolumn{2}{|c|}{ LGA } & \multicolumn{2}{|c|}{ CTL } & \multicolumn{2}{|c|}{$\mathrm{HC}$} \\
\hline & Elite & NA & Elite & NA & Elite & NA \\
\hline Fertilizer N & 250 & 250 & 250 & 250 & 250 & 250 \\
\hline $\mathrm{N}$ imported in silage & 3.6 & 3.9 & 20.3 & 18.7 & 1.4 & 0.7 \\
\hline $\mathrm{N}$ input in herd replacements & 4.8 & 7.4 & 4.9 & 7.4 & 5.0 & 7.5 \\
\hline Total $\mathrm{N}$ input & 282.7 & 285.5 & 299.3 & 300.1 & 341.8 & 342.6 \\
\hline Cull cow N & 6.0 & 9.2 & 6.1 & 9.2 & 6.2 & 9.4 \\
\hline Total N output & 93.6 & 93.0 & 101.3 & 94.1 & 111.8 & 104.8 \\
\hline $\mathrm{N}_{\text {surplus }}{ }^{3}$ & 189.1 & 192.5 & 198.0 & 206.1 & 230.1 & 237.8 \\
\hline $\mathrm{N}$ use efficiency ${ }^{4}$ & 0.331 & 0.326 & 0.339 & 0.313 & 0.327 & 0.306 \\
\hline
\end{tabular}

${ }^{1}$ Elite $=$ high economic breeding index $(\mathrm{EBI}) ; \mathrm{NA}=$ national average EBI.

${ }^{2} \mathrm{CTL}=$ high grass allowance; $\mathrm{HC}=$ high concentrate; LGA $=$ lower grass allowance FT.

${ }^{3}$ Total N input - total N output. ${ }^{4}$ Total $\mathrm{N}$ output/total N input. 
ment for imported silage and, thus, lower $\mathrm{N}$ imported into the system. However, this advantage is offset by the fact that the LGA had a greater carbon footprint and reduced economic performance (O'Sullivan et al., 2020b) compared with the CTL.

Selection for environmental traits within the EBI may be considered a strategy to improve environmental sustainability in the future. Potential traits might include urinary urea $\mathrm{N}$ content, $\mathrm{CH}_{4}$, or associated traits such as feed intake, with recent research showing promise for routinely collected proxies for these phenotypes (Vanlierde et al., 2016; Beatson et al., 2019; Lahart et al., 2019). Lassen and Difford (2020) proposed genomic selection as a method of increasing the rate of genetic gain for environmental traits. While Pryce and Haile-Mariam (2020) proposed merging international data sets, as per Berry et al. (2014) for feed intake, as a strategy to generate breeding values. The majority of these records, however, will likely be from animals housed indoors and offered energy-dense diets. Given the potential for genotype $\times$ environment interactions for feed intake between intensive indoor systems and grazing environments (Berry et al., 2014), such data may be of limited value to pasture-based systems. The biological implications of selecting for environmental traits should also be considered; Marshall et al. (2020) reported indirect selection for reduced urinary urea $\mathrm{N}$ content, via milk urea $\mathrm{N}$, may have a positive effect on milk protein percent, whereas selection for lower feed intake and $\mathrm{CH}_{4}$ production can negatively affect energy balance (Krattenmacher et al., 2019) and fertility (López-Paredes et al., 2020), respectively. In fact, O'Sullivan et al. (2019a) demonstrates that a greater feed intake capacity and slightly inferior feed efficiency in elite cows results in a more favorable energy status, which is associated with increased longevity and lifetime efficiency. Consequently, the incorporation of environmental traits to the EBI should only be considered if such traits can be implemented through balanced breeding indexes with appropriate weightings on all traits of economic importance.

\section{CONCLUSIONS}

The elite animals in the current study provide a futuristic view into the effect of selection using high EBI genetics on GHG emissions and N efficiency. The results demonstrate that selection using high EBI genetics will considerably reduce GHG emissions intensity across a range of pasture-based feeding scenarios, while contributing toward a small but favorable effect on $\mathrm{N}$ efficiency. Selection for the EBI will not reduce emissions per hectare unless milk output remains constant. Nonetheless, GHG emissions need to be considered on a global scale as milk production and associated environmental impacts in Ireland influence global emissions and food supply chains. Furthermore, the results of the current study emphasize the importance to avoid "system drift" leading to increased concentrate supplementation levels, as to do so would negatively affect environmental sustainability in the context of both GHG emissions and N efficiency within pasture-based systems. Further research should be conducted assessing the effect of incorporating environmental traits into the EBI.

\section{ACKNOWLEDGMENTS}

The authors acknowledge the contribution of the farm staff at the Dairygold research farm as well as a research grant from Science Foundation Ireland and the Department of Agriculture, Food and Marine on behalf of the Government of Ireland under the grant 16/RC/3835 (VistaMilk). The authors have not stated any conflicts of interest.

\section{REFERENCES}

ARC (Agricultural Research Council). 1994. Nutrient Requirements of Ruminant Livestock. Technical review by an Agricultural Research Council Working Party. CAB International.

Amer, P. R., F. S. Hely, C. D. Quinton, and A. R. Cromie. 2018. A methodology framework for weighting genetic traits that impact greenhouse gas emission intensities in selection indexes. Animal 12:5-11. https://doi.org/10.1017/S1751731117001549.

Beatson, P. R., S. Meier, N. G. Cullen, and H. Eding. 2019. Genetic variation in milk urea nitrogen concentration of dairy cattle and its implications for reducing urinary nitrogen excretion. Animal 13:2164-2171. https://doi.org/10.1017/S1751731119000235.

Berry, D. P., M. P. Coffey, J. E. Pryce, Y. de Haas, P. Løvendahl, N. Krattenmacher, J. J. Crowley, Z. Wang, D. Spurlock, K. Weigel, K. Macdonald, and R. F. Veerkamp. 2014. International genetic evaluations for feed intake in dairy cattle through the collation of data from multiple sources. J. Dairy Sci. 97:3894-3905. https://doi .org/10.3168/jds.2013-7548.

Brentrup, F., A. Hoxha, and B. Christensen. 2016. Carbon footprint analysis of mineral fertiliser production in Europe and other world regions. Pages 482-490 in The 10th International Conference on Life Cycle Assessment of Food University College Dublin, Dublin, Ireland. LCA Food 2016.

Brentrup, F., and C. Palliére. 2011. Energy efficiency and greenhouse gas emissions in European nitrogen fertiliser production and use. Sustainable agriculture in Europe. Fertiliser Europe.

Buckley, F., P. Dillon, M. Rath, and R. F. Veerkamp. 2000. The relationship between genetic merit for yield and live weight, condition score, and energy balance of spring calving Holstein Friesian dairy cows on grass based systems of milk production. J. Dairy Sci. 83:1878-1886. https://doi.org/10.3168/jds.S0022-0302(00)75060 -0 .

Buckley, F., K. O'Sullivan, J. F. Mee, R. D. Evans, and P. Dillon. 2003. Relationships among milk yield, body condition, cow weight, and reproduction in spring-calved Holstein-Friesians. J. Dairy Sci. 86:2308-2319. https://doi.org/10.3168/jds.S0022-0302(03)73823 $-5$.

Byrne, K. A., G. Kiely, and P. Leahy. 2005. $\mathrm{CO}_{2}$ fluxes in adjacent new and permanent temperate grasslands. Agric. For. Meteorol. 135:82-92. https://doi.org/10.1016/j.agrformet.2005.10.005. 
Byrne, K. A., G. Kiely, and P. Leahy. 2007. Carbon sequestration determined using farm scale carbon balance and eddy covariance. Agric. Ecosyst. Environ. 121:357-364. https://doi.org/10.1016/j agee.2006.11.015.

Capper, J. L., R. A. Cady, and D. Bauman. 2009. The environmental impact of dairy production: 1944 compared with 2007. J. Anim. Sci. 87:2160-2167. https://doi.org/10.2527/jas.2009-1781.

CSO (Central Statistics Office). 2020. Agricultural statistics database. Accessed Aug. 18, 2020. https://www.cso.ie/en/statistics/ agriculture/.

Ecoinvent. 2010. Ecoinvent database v 2.2. Swiss Centre for Life Cycle Inventories, Dübendorf.

EPA (Environmental Protection Agency). 2019a. Water quality in Ireland 2013-2018. Accessed Mar. 27, 2021. https://www.epa .ie/pubs/reports/water/waterqua/Water\%20Quality\%20in\%20 Ireland\%202013-2018\%20(web).pdf.

EPA. 2019b. Ireland's Informative Inventory Report-Air Pollutant Emissions in Ireland 1990-2017. P. Duffy, B. Hyde, A. M. Ryan, J. Murphy, B. Quirke, and D. Fahey, ed. Johnstown Castle, Co. Wexford, Ireland.

EPA. 2019c. Ireland's National Inventory Report 2019. In Greenhouse Gas Emissions 1990-2017. P. Duffy, K. Black, B. Hyde, A. M. Ryan, and M. J. Ponzi, ed. Johnstown Castle, Co. Wexford, Ireland.

EPA. 2020. Greenhouse gas emissions statistics from agriculture. Accessed Aug. 20, 2020. https://www.epa.ie/ghg/agriculture/.

European Union Water Framework Directive. 2000/60/EC. Accessed Mar. 30, 2021. https://eur-lex.europa.eu/legal-content/EN/TXT/ $\mathrm{PDF} /$ ?uri=CELEX:02000L0060-20141120\&from $=\mathrm{EN}$.

Evans, R. D., F. Buckley, P. Dillon, and R. F. Veerkamp. 2002. Genetic parameters for production and fertility in spring-calving Irish dairy cattle. Ir. J. Agric. Food Res. 41:43-54.

Forrestal, P. J., M. Harty, R. Carolan, G. J. Lanigan, C. J. Watson, R. J. Laughlin, G. McNeill, B. J. Chambers, and K. G. Richards. 2016. Ammonia emissions from urea, stabilized urea and calcium ammonium nitrate: insights into loss abatement in temperate grassland. Soil Use Manage. 32:92-100. https://doi.org/10.1111/ sum.12232.

Gerber, P., T. Vellinga, C. Opio, and H. Steinfeld. 2011. Productivity gains and greenhouse gas emissions intensity in dairy systems. Livest. Sci. 139:100-108. https://doi.org/10.1016/j.livsci.2011.03.012.

Harty, M. A., P. J. Forrestal, C. J. Watson, K. L. Mcgeough, R. Carolan, C. Elliot, D. Krol, R. J. Laughlin, K. G. Richards, and G. J. Lanigan. 2016. Reducing nitrous oxide emissions by changing $\mathrm{N}$ fertiliser use from calcium ammonium nitrate (CAN) to urea based formulations. Sci. Total Environ. 563-564:576-586. https:// doi.org/10.1016/j.scitotenv.2016.04.120.

Hutchinson, I. A., L. Shalloo, and S. T. Butler. 2013. Expanding the dairy herd in pasture-based systems: The role of sexed semen use in virgin heifers and lactating cows. J. Dairy Sci. 96:6742-6752. https://doi.org/10.3168/jds.2012-6476.

IDF (International Dairy Federation). 2010. A Common Carbon Footprint for Dairy. The IDF Guide to Standard Lifecycle Assessment Methodology for the Dairy Industry. Bulletin of the International Dairy Federation 445. International Dairy Federation, Brussels, Belgium.

IPCC (Intergovernmental Panel on Climate Change). 2019. Refinement to the 2006 IPCC guidelines for National Greenhouse Gas Inventories. Volume 4 Agriculture, Forestry and Other Land Use.

Jaksic, V., G. Kiely, J. Albertson, R. Oren, G. Katul, P. Leahy, and K. A. Byrne. 2006. Net ecosystem exchange of grassland in contrasting wet and dry years. Agric. For. Meteorol. 139:323-334. https:// doi.org/10.1016/j.agrformet.2006.07.009.

Jarrige, R. 1989. Ruminant nutrition: Recommended allowances and feed tables. John Libbey Eurotext.

Keim, J. P., and R. Anrique. 2011. Nutritional strategies to improve nitrogen use efficiency by grazing dairy cows. Chil. J. Agric. Res. 71:623-633. https://doi.org/10.4067/S0718-58392011000400019.

Kelly, P., L. Shalloo, M. Wallace, and P. Dillon. 2020. The Irish dairy industry-Recent history and strategy, current state and future challenges. Int. J. Dairy Tech. 73:309-323. https://doi.org/10 $.1111 / 1471-0307.12682$.

Krattenmacher, N., G. Thaller, and J. Tetens. 2019. Analysis of the genetic architecture of energy balance and its major determinants dry matter intake and energy-corrected milk yield in primiparous Holstein cows. J. Dairy Sci. 102:3241-3253. https://doi.org/10 .3168/jds.2018-15480.

Krol, D. J., R. Carolan, E. Minet, K. L. Mcgeough, C. J. Watson, P. J. Forrestal, G. J. Lanigan, and K. G. Richards. 2016. Improving and disaggregating $\mathrm{N}_{2} \mathrm{O}$ emission factors for ruminant excreta on temperate pasture soils. Sci. Total Environ. 568:327-338. https:// doi.org/10.1016/j.scitotenv.2016.06.016.

Lahart, B., S. McParland, E. Kennedy, T. M. Boland, T. Condon, M. Williams, N. Galvin, B. McCarthy, and F. Buckley. 2019. Predicting the dry matter intake of grazing dairy cows using infrared reflectance spectroscopy analysis. J. Dairy Sci. 102:8907-8918. https: //doi.org/10.3168/jds.2019-16363.

Lassen, J., and G. F. Difford. 2020. Genetic and genomic selection as a methane mitigation strategy in dairy cattle. Animal 14:s473-s483. https://doi.org/10.1017/S1751731120001561.

Leip, A., F. Weiss, T. Wassenaar, I. Perez, T. Fellmann, P. Loudjani, F. Tubiello, D. Grandgirard, S. Monni, and K. Biala. 2010. Evaluation of the livestock sector's contribution to the EU greenhouse gas emissions (GGELS)-final report. European Commission, Joint Research Centre 32.

López-Paredes, J., I. Goiri, R. Atxaerandio, A. García-Rodríguez, E. Ugarte, J. A. Jiménez-Montero, R. Alenda, and O. González-Recio. 2020. Mitigation of greenhouse gases in dairy cattle via genetic selection: 1. Genetic parameters of direct methane using noninvasive methods and proxies of methane. J. Dairy Sci. 103:7199-7209. https://doi.org/10.3168/jds.2019-17597.

Marshall, C. J., M. R. Beck, K. Garrett, G. K. Barrell, O. Al-Marashdeh, and P. Gregorini. 2020. Grazing dairy cows with low milk urea nitrogen breeding values excrete less urinary urea nitrogen. Sci. Total Environ. 739:139994. https://doi.org/10.1016/j.scitotenv .2020.139994.

McDonald, P. 2002. Animal Nutrition. Pearson Education.

Mottet, A., F. Teillard, P. Boettcher, G. De'Besi, and B. Besbes. 2018. Domestic herbivores and food security: Current contribution, trends and challenges for a sustainable development. Animal 12:s188-s198. https://doi.org/10.1017/S1751731118002215.

Myhre, G., D. Shindell, F. M. Bréon, W. Collins, J. Fuglestvedt, J. Huang, D. Koch, J. F. Lamarque, D. Lee, B. Mendoza, T. Nakajima, A. Robock, G. Stephens, T. Takemura, and H. Zhang. 2013. Anthropogenic and natural radiative forcing. Pages 712-716 in Climate Change 2013: The Physical Science Basis. Contribution of Working Group I to the Fifth Assessment Report of the Intergovernmental Panel on Climate Change. T. F. Stocker, D. Qin, G. K. Plattner, M. Tignor, S. K. Allen, J. Boschung, A. Nauels, Y. Xia, V. Bex, and P. M. Midgley, ed. Cambridge University Press. https://doi.org/10.1017/CBO9781107415324.018.

O'Brien, D., A. Geoghegan, K. McNamara, and L. Shalloo. 2016. How can grass-based dairy farmers reduce the carbon footprint of milk? Anim. Prod. Sci. 56:495-500. https://doi.org/10.1071/AN15490.

O'Brien, D., T. Hennessy, B. Moran, and L. Shalloo. 2015. Relating the carbon footprint of milk from Irish dairy farms to economic performance. J. Dairy Sci. 98:7394-7407. https://doi.org/10.3168/ jds.2014-9222.

O'Brien, D., B. Moran, and L. Shalloo. 2018. A national methodology to quantify the diet of grazing dairy cows. J. Dairy Sci. 101:85958604. https://doi.org/10.3168/jds.2017-13604.

O'Brien, D., L. Shalloo, C. Grainger, F. Buckley, B. Horan, and M. Wallace. 2010. The influence of strain of Holstein-Friesian cow and feeding system on greenhouse gas emissions from pastoral dairy farms. J. Dairy Sci. 93:3390-3402. https://doi.org/10.3168/jds .2009-2790.

O'Brien, D., L. Shalloo, J. Patton, F. Buckley, C. Grainger, and M. Wallace. 2012. Evaluation of the effect of accounting method, IPCC v. LCA, on grass-based and confinement dairy systems' greenhouse gas emissions. Animal 6:1512-1527. https://doi.org/10 .1017/S1751731112000316. 
O'Connor, A. H., E. A. M. Bokkers, I. J. M. de Boer, H. Hogeveen, R. Sayers, N. Byrne, E. Ruelle, and L. Shalloo. 2020. Associating mobility scores with production and reproductive performance in pasture-based dairy cows. J. Dairy Sci. 103:9238-9249. https://doi .org/10.3168/jds.2019-17103.

O'Donovan, M., E. Lewis, and P. O'Kiely. 2011. Requirements of future grass-based ruminant production systems in Ireland. Ir. J. Agric. Food Res. 50:1-21. https://www.jstor.org/stable/41348152.

O'Sullivan, M., S. Butler, K. M. Pierce, M. Crowe, K. O'Sullivan, R. Fitzgerald, and F. Buckley. 2020a. Reproductive efficiency and survival of Holstein-Friesian cows of divergent Economic Breeding Index, evaluated under seasonal calving pasture-based management. J. Dairy Sci. 103:1685-1700. https://doi.org/10.3168/jds .2019-17374.

O'Sullivan, M., P. Dillon, K. O'Sullivan, K. M. Pierce, N. Galvin, M. Egan, and F. Buckley. 2019a. Intake, efficiency, and feeding behavior characteristics of Holstein-Friesian cows of divergent Economic Breeding Index evaluated under contrasting pasture-based feeding treatments. J. Dairy Sci. 102:8234-8246. https://doi.org/10.3168/ jds.2019-16371.

O'Sullivan, M., B. Horan, K. M. Pierce, S. McParland, K. O'Sullivan, and F. Buckley. 2019b. Milk production of Holstein-Friesian cows of divergent Economic Breeding Index evaluated under seasonal pasture-based management. J. Dairy Sci. 102:2560-2577. https:// doi.org/10.3168/jds.2018-15559.

O'Sullivan, M., L. Shalloo, K. M. Pierce, and F. Buckley. 2020b. Economic assessment of Holstein-Friesian dairy cows of divergent Economic Breeding Index evaluated under seasonal calving pasturebased management. J. Dairy Sci. 103:10311-10320. https://doi .org/10.3168/jds.2019-17544.

Powell, J. M., C. J. P. Gourley, C. A. Rotz, and D. M. Weaver. 2010. Nitrogen use efficiency: A potential performance indicator and policy tool for dairy farms. Environ. Sci. Policy 13:217-228. https: //doi.org/10.1016/j.envsci.2010.03.007.

Pryce, J. E., and M. Haile-Mariam. 2020. Symposium review: Genomic selection for reducing environmental impact and adapting to climate change. J. Dairy Sci. 103:5366-5375. https://doi.org/10 $.3168 /$ jds.2019-17732.

Ramsbottom, G., A. R. Cromie, B. Horan, and D. P. Berry. 2012. Relationship between dairy cow genetic merit and profit on commercial spring calving dairy farms. Animal 6:1031-1039. https:// doi.org/10.1017/S1751731111002503.

Roche, J., D. P. Berry, L. Delaby, P. Dillon, B. Horan, K. Macdonald, and M. Neal. 2018. New considerations to refine breeding objectives of dairy cows for increasing robustness and sustainability of grass-based milk production systems. Animal 12:s350-s362. https: //doi.org/10.1017/S1751731118002471.

Ryan, W., D. Hennessy, J. Murphy, T. M. Boland, and L. Shalloo. 2011. A model of nitrogen efficiency in contrasting grass-based dairy systems. J. Dairy Sci. 94:1032-1044. https://doi.org/10 $.3168 / \mathrm{jds} .2010-3294$.

Schader, C., A. Muller, N. E.-H. Scialabba, J. Hecht, A. Isensee, K.-H. Erb, P. Smith, H. P. S. Makkar, P. Klocke, F. Leiber, P. Schwegler, M. Stolze, and U. Niggli. 2015. Impacts of feeding less food-competing feedstuffs to livestock on global food system sustainability. J. R. Soc. Interface 12:20150891. https://doi.org/10.1098/rsif.2015 .0891.

Shalloo, L., P. Dillon, M. Rath, and M. Wallace. 2004. Description and validation of the Moorepark dairy system model. J. Dairy Sci. 87:1945-1959. https://doi.org/10.3168/jds .S0022-0302(04)73353-6.

Snijders, S. E. M., P. G. Dillon, K. J. O'Farrell, M. Diskin, A. R. G. Wylie, D. O'Callaghan, M. Rath, and M. P. Boland. 2001. Genetic merit for milk production and reproductive success in dairy cows. Anim. Reprod. Sci. 65:17-31. https://doi.org/10.1016/S0378 -4320(00)00217-7.

Sustainable Energy Authority of Ireland (SEAI). 2018. Energy in Ireland-2018 Report. Dublin, Ireland.

Teagasc. 2020. 2027 Sectorial Roadmap: Dairy. Accessed Dec. 14, 2020. https://www.teagasc.ie/media/website/publications/2020/ Road-Map-2027-Dairy-201120.pdf.

Vanlierde, A., M. L. Vanrobays, N. Gengler, P. Dardenne, E. Froidmont, H. Soyeurt, S. McParland, E. Lewis, M. H. Deighton, M. Mathot, and F. Dehareng. 2016. Milk mid-infrared spectra enable prediction of lactation-stage-dependent methane emissions of dairy cattle within routine population-scale milk recording schemes. Anim. Prod. Sci. 56:258-264. https://doi.org/10.1071/AN15590.

Veerkamp, R. F., P. Dillon, E. Kelly, A. R. Cromie, and A. F. Groen. 2002. Dairy cattle breeding objectives combining yield, survival and calving interval for pasture-based systems in Ireland under different milk quota scenarios. Livest. Prod. Sci. 76:137-151. https: //doi.org/10.1016/S0301-6226(02)00006-4.

Yan, T., R. E. Agnew, F. J. Gordon, and M. G. Porter. 2000. Prediction of methane energy output in dairy and beef cattle offered grass silage-based diets. Livest. Prod. Sci. 64:253-263. https://doi .org/10.1016/S0301-6226(99)00145-1.

Zhang, X., P. R. Amer, G. M. Jenkins, J. A. Sise, B. Santos, and C. Quinton. 2019. Prediction of effects of dairy selection indexes on methane emissions. J. Dairy Sci. 102:11153-11168. https://doi .org/10.3168/jds.2019-16943. 